\title{
Induction of transgenic hairy roots in soybean genotypes by Agrobacterium rhizogenes-mediated transformation
}

\author{
Ricardo Luís Mayer Weber ${ }^{(1)}$ and Maria Helena Bodanese-Zanettini ${ }^{(1)}$ \\ (1)Universidade Federal do Rio Grande do Sul, Departamento de Genética, Instituto de Biociências, Caixa Postal 15.053, CEP 91501-970 \\ Porto Alegre, RS, Brazil. E-mail: rlmweber@yahoo.com.br, maria.zanettini@ufrgs.br
}

\begin{abstract}
The objective of this work was to perform the screening of soybean genotypes as to their ability to respond to the induction of hairy roots by Agrobacterium rhizogenes-mediated transformation. Four Brazilian soybean cultivars (BRSMG 68 Vencedora, BRS 137, Embrapa 48, and MG/BR 46 Conquista) and two North American ones adapted to Brazilian cropping conditions (Bragg and IAS-5) were screened for their capacity to respond to $A$. rhizogenes in protocols for in vitro hairy root culture and ex vitro composite plant production. Four-day-old seedlings with uniform size were injected with $A$. rhizogenes harboring the plasmid p35S-GFP. Seedlings expressing green fluorescent protein (GFP) in at least one hairy root were used to determine the transformation frequency. Using an axenic in vitro protocol, excised cotyledons from four-day-old seedlings were infected with $A$. rhizogenes harboring the pCAMBIA1301 plasmid, containing the gusA reporter gene. The transformation frequency and the number of days for hairy root emergence after bacterial infection (DAI) were evaluated. The transformation frequency and DAI varied according to the genotype. Cultivars MG/BR 46 Conquista and BRSMG 68 Vencedora are more susceptible to A. rhizogenes and can be recommended for transformation experiments.
\end{abstract}

Index terms: Glycine max, composite plants, genetic transformation, hairy roots culture, strain K599.

\section{Indução de raízes fasciculadas transgênicas em genótipos de soja por transformação mediada por Agrobacterium rhizogenes}

Resumo - $\mathrm{O}$ objetivo deste trabalho foi realizar a triagem de genótipos de soja quanto à sua habilidade de resposta à indução de raízes fasciculadas por transformação mediada por Agrobacterium rhizogenes. Quatro cultivares brasileiras de soja (BRSMG 68 Vencedora, BRS 137, Embrapa 48 e MG/BR 46 Conquista) e duas norte americanas, adaptadas às condições brasileiras de cultivo (Bragg e IAS-5), foram avaliadas quanto à sua capacidade de responder a $A$. rhizogenes, em protocolos de cultura de raízes fasciculadas in vitro e de produção ex vitro de plantas compostas. Plântulas com quatro dias de idade, de tamanho uniforme, foram injetadas com A. rhizogenes portando o plasmídeo p35S-GFP. As plântulas que expressaram a proteína verde fluorescente (GFP) em pelo menos uma raiz foram utilizadas para determinar a frequência de transformação. Utilizando um protocolo de obtenção de raízes axênicas, in vitro, cotilédones excisados de plântulas com quatro dias de idade foram infectados com A. rhizogenes portando o plasmídeo pCAMBIA1301 contendo o gene repórter gusA. Foram avaliados a frequência de transformação e o número de dias para emergência das raízes fasciculadas após a infecção bacteriana (DAI). A frequência de transformação e o DAI variaram conforme o genótipo. As cultivares MG/BR 46 Conquista e BRSMG 68 Vencedora são mais suscetíveis a $A$. rhizogenes e podem ser recomendadas para experimentos de transformação.

Termos para indexação: Glycine max, plantas compostas, transformação genética, cultura de raízes fasciculadas, linhagem K599.

\section{Introduction}

Agrobacterium tumefaciens-mediated transformation and particle bombardment are the two major extensively employed methods for soybean (Glycine max L.) transformation (Hinchee et al., 1988; Homrich et al., 2008; Schmidt et al., 2008). Wiebke-Strohm et al. (2011) recently reported the recovery of the first soybean transgenic fertile plants obtained from somatic embryogenic tissues transformed by a system that combines DNA-free particle bombardment and A.tumefaciens-mediated transformation. Both methods

Pesq. agropec. bras., Brasília, v.46, n.9, p.1070-1075, set. 2011 
have limitations, such as a prolonged tissue culture period and intensive labor, and are quite expensive and not entirely suitable for high-throughput analyses, which restrict their potential as objects for gene functional studies.

Agrobacterium rhizogenes, a Gram-negative phytopathogenic bacterium, causes the production of adventitious hairy roots at wounding sites. The transformation mediated by this species leads to the development of the hairy root phenotype, which consists of highly branched roots that grow rapidly and plagiotropically in the absence of exogenous plant growth regulators (Collier et al., 2005). The bacteria can transfer T-DNA from Ri plasmid into the plant genome and T-DNA of the binary vector when co-transferred (Christey, 2001; Broothaerts et al., 2005). Agrobacterium rhizogenes mediated-transformation has become a powerful tool for gene function and root biology studies, due to its quick and simple methodology (Cao et al., 2009).

The production of axenic hairy root cultures is an interesting tool, because the transgenic root explants can be clonally propagated in studies of, for example, endomycorrhizal colonization (Chabaud et al., 2002). Unfortunately, this kind of clonal explant cannot be used for nodulation studies, since legume interaction with Rhizobium requires aerial organs (Chabaud et al., 2006). Composite plants, consisting of wild-type shoots with transgenic roots, represent a significant advance, as they allow transgene root testing in a complete plant (Collier et al., 2005). These composite plants can be obtained by both protocols, in vitro or ex vitro, depending on the objective of the study.

The $A$. rhizogenes-mediated transformation system was found to be very useful in genetic manipulation of plants of the family Fabaceae, such as Medicago truncatula (Crane et al., 2006) and Phaseolus spp. (Estrada-Navarrete et al., 2007). In soybean, the method has been used to characterize promoters (Hernandez-Garcia et al., 2010) and in studies of nematode propagation (Cho et al., 2000), symbiotic (Hayashi et al., 2008) and pathogenic interactions (Li et al., 2010), besides RNAi silencing of genes (Subramanian et al., 2005). Although regeneration of whole transgenic soybean plants from hairy root cultures has not yet been reported, the major advantage of this method is a relative short period (about 6-8 weeks) to screen potential genes and promoters useful to genetic improvement in stably-transformed tissues (Cho et al., 2000). Since every transgenic root represents an independent transformation event, high numbers of transformants can be obtained and analyzed in a relatively short period of time (Kereszt et al., 2007).

The efficiency of hairy root induction can vary considerably among genotypes (Savka et al., 1990; Mazarei et al., 1998; Cho et al., 2000; Cao et al., 2009). Genotype dependence justifies the screening of soybean cultivars that are more responsive to the induction of hairy roots by $A$. rhizogenes. However, there is no known information on the capacity of Brazilian soybean genotypes to respond to the induction of hairy roots by $A$. rhizogenes.

The objective of this work was to perform the screening of soybean genotypes as to their ability to respond to the induction of hairy roots by A. rhizogenes-mediated transformation.

\section{Materials and Methods}

Six soybean cultivars, IAS-5, Bragg, BRSMG 68 Vencedora, BRS 137, Embrapa 48, and MG/BR 46 Conquista, were tested in order to evaluate the effect of plant genotype in A. rhizogenes-mediated transformation. Bragg and IAS-5 are North American cultivars adapted to Brazilian cropping conditions, commonly used in genetic improvement programs, whereas all the others are Brazilian cultivars developed and released by Brazilian breeding programs and recommended for commercial growth in different states of the country (Brasil, 2009). The cultivars Bragg, IAS-5, and BRSMG 68 Vencedora were chosen due to their high sensitivity towards A. tumefaciens (Wiebke-Strohm et al., 2011), while MG/BR 46 Conquista was included in the tests because it had been selected as a model cultivar in the Brazilian Soybean Genome Consortium (Genosoja).

Soybean seeds were surface disinfested for $30 \mathrm{~s}$ in $70 \%$ ethanol and $15 \mathrm{~min}$ in $4 \%$ sodium hypochlorite, containing Tween 20 (Sigma-Aldrich, Vienna, Austria). After disinfestation, seeds were rinsed four times in sterile distilled water and then germinated in plastic pots with sterile vermiculite, covered with transparent plastic film to keep high humidity, and maintained in greenhouse at $25 \pm 1^{\circ} \mathrm{C}$ under fluorescent light with a 16-hour photoperiod. 
The vector pCAMBIA1301 (Cambia, Brisbane, Australia) and a pDE1001, with green fluorescent protein(GFP) expressioncassettefromthepPK100vector, hereby named p35S-GFP, constructed by Mangeon et al. (2009), were introduced by electrotransformation into A. rhizogenes strain K599. Agrobacterium rhizogenes without the binary vector was grown in LB medium, lacking antibiotics. Then, single isolated colonies were incubated for 48 hours at $28^{\circ} \mathrm{C}$ in $5 \mathrm{~mL}$ liquid LB media, with the adequate antibiotics, and grown under orbital shaking at $180 \mathrm{rpm}$.

To assess the ability of the different cultivars for the induction of hairy roots in ex vitro condition, four-day-old seedlings with uniform size were injected with $A$. rhizogenes harboring the plasmid p35S-GFP by stabbing at the cotyledonary node with a syringe, as described by Kereszt et al. (2007). Thirty plants were inoculated for each genotype. The plants were maintained covered with transparent plastic film in greenhouse at $25 \pm 1{ }^{\circ} \mathrm{C}$ under fluorescent light with a 16-hour photoperiod. The plants were analyzed to GFP expression when hairy roots were about $2 \mathrm{~cm}$ long. Seedlings expressing the GFP in at least one hairy root were evaluated in order to determine the transformation frequency. GFP expression was detected under blue light using an inverted microscope CKX41, (Olympus, Tokyo, Japan), equipped with a BP filter set containing a $488 \mathrm{~nm}$ excitation filter and a 505-530 $\mathrm{nm}$ emission filter. Hairy roots from seedlings transformed with A. rhizogenes strain K599 without any plasmid were used as negative control. Images were captured using the software QCapture ProTM 6 (QImaging, Surrey, Canada).

Axenic in vitro transgenic hairy root cultures were obtained according to Hernandez-Garcia et al. (2010), with modifications. Fifty cotyledons from four-day-old plants of each genotype were excised briefly, surface-sterilized as described for seeds, and placed in Petri dishes containing three sterile filter paper sheets moistened with sterile distilled water. Then, the cotyledons were uniformly wounded three times on the abaxial side with a sterile scalpel dipped in an overnight bacterial culture harboring the plasmid pCAMBIA1301, and incubated at $25 \pm 1^{\circ} \mathrm{C}$ under fluorescent light with a 16-hour photoperiod. Three days after infection, the cotyledons were transferred onto the medium containing MS salts (Murashige \& Skoog, 1962), B5 vitamins (Gamborg et al., 1968), 3\% sucrose, $0.3 \%$ Phytagel, $\mathrm{pH} 6.4$ (prior to autoclaving), and $500 \mathrm{mg} \mathrm{L}^{-1}$ of carbenicillin to inhibit bacterial growth. The number of days for hairy root emergence after bacterial infection (DAI) was recorded (Cao et al., 2009). After root emergence, 2-cm long root tips were transferred to the same medium with hygromycin B to select transformed hairy roots. Hygromycin B selection was done with $25 \mathrm{mg} \mathrm{L}^{-1}$, the usual concentration used for selection of transformed somatic embryos in the laboratory (Homrich et al., 2008; Wiebke-Strhom et al., 2011). To guarantee the identity of independent transformation events, a single vigorous root from each cotyledon was transferred to the selection medium. About one week later, only roots that showed growth in the medium with the antibiotics were used to establish new root cultures. Two-centimeter long root tips were used as explants and were subcultured every week (three subcultures) to a fresh medium with antibiotics. For negative control, roots induced by wild-type strain K599 were maintained in the same medium, without the selective antibiotic. Transformation frequency was calculated by the number of roots expressing the gus A gene (after three weeks in selection medium) divided by the total number of inoculated cotyledons.

In order to confirm that hairy root cultures were free from $A$. rhizogenes, after three weeks, root samples of the selective medium were plated on LB agar medium. Plates were incubated for two days at $28^{\circ} \mathrm{C}$, and the absence of bacterial growth was an indicator that A. rhizogenes was completely eliminated from the tissues.

The expression of gusA gene was assayed by histochemical staining, according to Jefferson (1987). Both wild-type (negative control) and putative transformed roots were incubated in a 5-bromo-4-chloro-3-indolyl-glucuronide (X-Gluc) solution, at $37^{\circ} \mathrm{C}$, in the dark. Gene expression was visualized after the roots had been washed in $70 \%$ ethanol and rehydrated with distillated water.

Genomic DNA was extracted from untransformed and in vitro putative transformed hairy root cultures according to the CTAB procedure described by Doyle \& Doyle (1987), with some modifications. Purified DNA samples from roots transformed by plasmid pCAMBIA1301 were PCR-screened using specific primers for $h p t \mathrm{II}$ gene (5'-GCGATTGCTGATCCCCATGTGTAT-3' and 5'-GGTTTCCACTATCGGCGAGTACTT-3'). 
The PCR reaction mixture consisted of $100 \mathrm{ng}$ of template DNA, $0.2 \mathrm{mmol} \mathrm{L}^{-1}$ of dNTPs, $1.5 \mathrm{mmol} \mathrm{L}^{-1}$ of $\mathrm{MgCl}_{2}, 1 \mathrm{X}$ Taq Buffer, 2 units of Taq DNA polymerase (Invitrogen, Carlsbad, CA, USA), and $0.5 \mu \mathrm{mol} \mathrm{L} \mathrm{L}^{-1}$ of each primer. Reactions were hot-started $(5 \mathrm{~min}$ at $94^{\circ} \mathrm{C}$ ) and subjected to 30 cycles: $45 \mathrm{~s}$ at $94^{\circ} \mathrm{C}, 45 \mathrm{~s}$ at $52^{\circ} \mathrm{C}$, and $45 \mathrm{~s}$ at $72^{\circ} \mathrm{C}$, with a final extension of $72^{\circ} \mathrm{C}$ for $5 \mathrm{~min}$. The $1 \%$ agarose gel was stained with ethidium bromide and visualized under UV light.

Data from DAI were analyzed with SPSS for Windows (SPSS Inc., Chicago, IL, USA), using the least significant difference (LSD) multiple comparison test, at $5 \%$ probability.

\section{Results and Discussion}

Transgenic hairy roots were induced in all genotypes infected by $A$. rhizogenes harboring the p35S-GFP vector, using the ex vitro protocol (Table 1). When observed under blue light, transgenic hairy roots were fluorescent green, confirming the transgene stable integration and expression (Figure 1).

Similarly to the ex vitro experiment, all analyzed cultivars were able to produce transgenic hairy roots using the in vitro protocol (Table 1). The expression of gus A gene was detected in all transformed roots that had survived the three subcultures on selective medium with hygromycin B. However, it was not observed in roots induced by the wild-type strain K599 (negative control), indicating that the staining was due to the insertion of the gusA gene into the plant genome (Figure 2). The use of a gusA-intron gene, present in the

Table 1. Ex vitro and in vitro Agrobacterium rhizogenesmediated transformation frequency (\%) and days for hairy root emergence after bacterial infection (DAI) in six soybean genotypes ${ }^{(1)}$.

\begin{tabular}{lccc}
\hline Genotype & \multicolumn{2}{c}{ Transformation frequency ${ }^{(2)}$} & \multirow{2}{*}{ DAI } \\
\cline { 2 - 3 } & Ex vitro & In vitro & \\
\hline Bragg & 36.7 & 14 & $13.1 \pm 0.9 \mathrm{a}$ \\
BRS 137 & 36.7 & 18 & $14.8 \pm 1.4 \mathrm{a}$ \\
BRSMG 68 Vencedora & 73.3 & 40 & $11.1 \pm 0.7 \mathrm{~b}$ \\
Embrapa 48 & 13.3 & 18 & $14.5 \pm 2.1 \mathrm{a}$ \\
IAS-5 & 66.7 & 24 & $14.6 \pm 1.1 \mathrm{a}$ \\
MG/BR 46 Conquista & 83.3 & 52 & $10.6 \pm 0.8 \mathrm{~b}$ \\
\hline
\end{tabular}

${ }^{(1)}$ Means \pm SE followed by equal letters do not differ by the LSD test, at $5 \%$ probability. ${ }^{(2)}$ In the ex vitro protocol, transformation frequency (TF) was calculated as: $\mathrm{TF}=$ number of seedlings expressing green fluorescent protein (GFP)/total number of seedlings inoculated; and in the in vitro protocol as: $\mathrm{TF}=$ the number of $\mathrm{GUS}^{+}$hairy root/total number of cotyledons inoculated.
T-DNA of pCAMBIA1301 vector, guaranteed a reliable result, since this gene can only be fully expressed in eukaryotic cells (Hiei et al., 1994). Analysis confirmed that no hptII amplification was detected in the negative controls, whereas all transformed materials, after three weeks in selective medium, had the expected $512 \mathrm{bp}$ of hpt II fragment (Figure $2 \mathrm{C}$ ).

The results obtained in the present study show that false-positive transformed hairy roots (escapes) were not detected under hygromycin B selection. This can be attributed to the fact that only hairy roots that survived three weeks in selective medium were analyzed. According to Li et al. (2010), $200 \mathrm{mg} \mathrm{L}^{-1}$ of kanamycin or $20 \mathrm{mg} \mathrm{L}^{-1}$ of hygromycin B can be used for efficient selection of soybean hairy root cultures. Stable soybean hairy root cultures have been obtained using kanamycin as selective antibiotic (Cho et al., 2000; Preiszner et al., 2001; Li et al., 2010).

Using the ex vitro protocol, the transformation frequency varied among genotypes. The cultivars MG/BR 46 Conquista and BRSMG 68 Vencedora had the highest transformation frequency (Table 1). Intermediary transformation frequency was observed for IAS-5, while transformation frequencies below $50 \%$ were obtained for Bragg, BRS 137, and Embrapa 48. Similarly to the ex vitro experiment, the genotypes MG/ BR 46 Conquista and BRSMG 68 Vencedora showed the highest transformation frequencies in axenic in vitro conditions. These cultivars were also the most precocious for root emergency after bacterial inoculation.

Mazarei et al. (1998) reported hairy root induction efficiency ranging from 5 to $90 \%$ in nine soybean genotypes. Savka et al. (1990) observed similar results, with transformation efficiency ranging from 5 to $85 \%$,

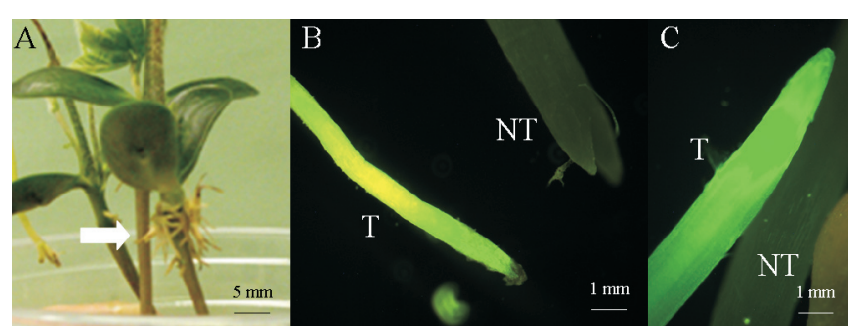

Figure 1. Green fluorescent protein (GFP) expression in soybean transgenic hairy roots obtained from the ex vitro Agrobacterium rhizogenes-mediated transformation. A, hairy roots induced from inoculated seedlings; B and C, GFP expression of transgenic hairy roots $(\mathrm{T})$ and non-transgenic (NT) plants, observed using an inverted microscope. 


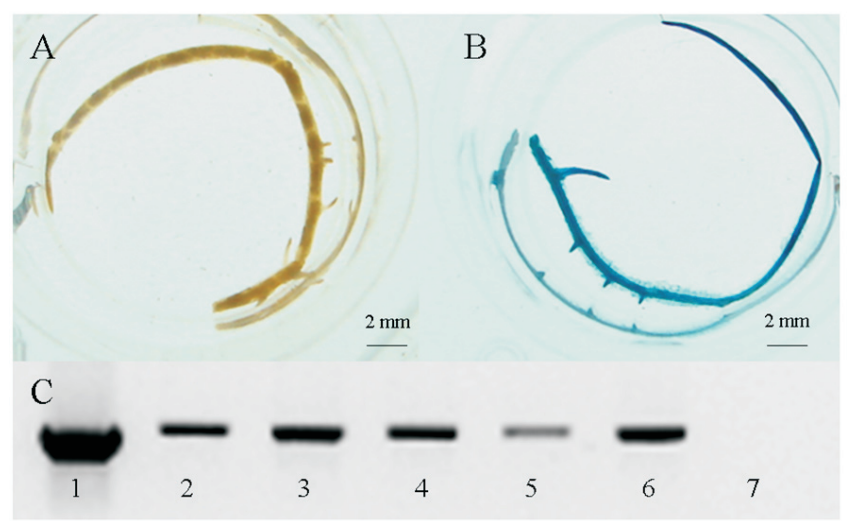

Figure 2. Expression of gus A gene in soybean hairy roots from in vitro protocol and PCR amplification of $h p t I I$ gene. A, hairy root induced by wild-type Agrobacterium rhizogenes strain K599; B, hairy root induced by A. rhizogenes strain K599 with pCAMBIA1301 vector; C, 1, positive control (pCAMBIA1301); 2-6, sample of PCR products amplified from DNA templates extracted from hairy roots of cultivar MG/BR 46 Conquista transformed with pCAMBIA1301, after three weeks in selection medium; 7, negative control hairy root induced by wild-type K599.

in ten North American genotypes. In both studies, the genotype capacity to induce hairy roots was evaluated using cotyledons as the explants (in vitro protocol) and wild-type bacteria. Using the ex vitro protocol, Cao et al. (2009) recorded a transformation frequency of 30 to $93.3 \%$ among seven Chinese genotypes. Cho et al. (2000) found transformation frequencies from 54 to $95 \%$, using an in vitro experiment. According to Cao et al. (2009), it is desirable for soybean genotypes to have short DAI, a large number of hairy roots, and a high transformation frequency in the hairy root transformation system.

\section{Conclusions}

1. All tested soybean genotypes can be transformed by the Agrobacterium rhizogenes-mediated method.

2. MG/BR 46 Conquista and BRSMG 68 Vencedora have higher transformation frequency and shorter period for hairy root induction after bacterial infection, and are the most recommended cultivars for in vitro and ex vitro genetic transformation mediated by A. rhizogenes.

\section{Acknowledgements}

To Dr. Gilberto Sachetto-Martins, from Universidade Federal do Rio de Janeiro, RJ, Brazil, for the supply of
p35S-GFP; and to Dr. Eliane Santarém, from Pontifícia Universidade Católica do Rio Grande do Sul, RS, Brazil, for the supply of A. rhizogenes strain K599.

\section{References}

BRASIL. Ministério da Agricultura, Pecuária e Abastecimento. Zoneamento agrícola de risco climático: cultivares de soja ano-safra 2008/2009. Disponível em: <www.agricultura.gov.br>. Acesso em: 4 nov. 2009.

BROOTHAERTS, W.; MITCHELL, H.J.; WEIR, B.; KAINES, S.; SMITH, L.M.A.; YANG, W.; MAYER, J.E.; ROA-RODRIGUEZ, C.; JEFFERSON, R.A. Gene transfer to plants by diverse species of bacteria. Nature, v.433, p.629-633, 2005.

CAO, D.; HOU, W.; SONG, S.; SUN, H.; WU, C.; GAO, Y.; HAN, T. Assessment of conditions affecting Agrobacterium rhizogenes-mediated transformation of soybean. Plant Cell Tissue and Organ Culture, v.96, p.45-52, 2009.

CHABAUD, M.; BOISSON-DERNIER, A.; ZHANG, J.; TAYLOR, C.G.; YU, O.; BARKER, D.G. Agrobacterium rhizogenes-mediated root transformation. In: MATHESIUS, U.; JOURNET, E.P.; SUMNER, L.W. Medicago truncatula handbook. St. Louis: Samuel Roberts Noble Foundation, 2006. Available at: <http://www.noble.org/medicagohandbook/pdf/ AgrobacteriumRhizogenes.pdf $>$. Accessed on: 28 Sept. 2011.

CHABAUD, M.; VENARD, C.; DEFAUX-PETRAS, A.; BECARD, G.; BARKER, D.G. Targeted inoculation of Medicago truncatula in vitro root cultures reveals MtENOD11 expression during early stages of infection by arbuscular mycorrhizal fungi. New Phytologist, v.156, p.265-273, 2002.

CHO, H.-J.; FARRAND, S.K.; NOEL, G.R.; WIDHOLM, J.M. High-efficiency induction of soybean hairy roots and propagation of the soybean cyst nematode. Planta, v.210, p.195-204, 2000.

CHRISTEY, M.C. Invited review: use of Ri-mediated transformation for production of transgenic plants. In Vitro Cellular and Developmental Biology - Plant, v.37, p.687-700, 2001.

COLLIER, R.; FUCHS, B.; WALTER, N.; LUTKE, W.K.; TAYLOR, C.G. Ex vitro composite plants: an inexpensive, rapid method for root biology. The Plant Journal, v.43, p.449-457, 2005.

CRANE, C.; WRIGHT, E.; DIXON, R.A.; WANG, Z.Y. Transgenic Medicago truncatula plants obtained from Agrobacterium tumefaciens-transformed roots and Agrobacterium rhizogenes-transformed hairy roots. Planta, v.223, p.1344-1354, 2006.

DOYLE, J.J.; DOYLE, J.L. A rapid DNA isolation procedure for small quantities of fresh leaf tissue. Phytochemical Bulletin, v.19, p.11-15, 1987.

ESTRADA-NAVARRETE, G.; ALVARADO-AFFANTRANGER, X.; OLIVARES, J.-E.; GUILLEN, G.; DIAZ-CAMINO, C.; CAMPOS, F.; QUINTO, C.; GRESSHOFF, P.M.; SANCHEZ, F. Fast, efficient and reproducible genetic transformation of Phaseolus spp. by Agrobacterium rhizogenes. Nature Protocols, v.2, p.1819-1824, 2007. 
GAMBORG, O.L.; MILLER, R.A.; OJIMA, K. Nutrient requirements of suspension cultures of soybean root cells. Experimental Cell Research, v.50, p.151-158, 1968.

HAYASHI, S.; GRESSHOFF, P.M.; KINKEMA, M. Molecular analysis of lipoxygenases associated with nodule development in soybean. Molecular Plant-Microbe Interactions, v.21, p.843-853, 2008.

HERNANDEZ-GARCIA, C.M.; BOUCHARD, R.A.; RUSHTON, P.J.; JONES, M.L.; CHEN, X.F.; TIMKO, M.P.; FINER, J.J. High level transgenic expression of soybean (Glycine max) GmERF and $G m u b i$ gene promoters isolated by a novel promoter analysis pipeline. BMC Plant Biology, v.10, p.237, 2010.

HIEI, Y.; OHTA, S.; KOMARI, T.; KUMASHIRO, T. Efficient transformation of rice (Oryza sativa L.) mediated by Agrobacterium and sequence analysis of the boundaries of the T-DNA. The Plant Journal, v.6, p.271-282, 1994.

HINCHEE, M.A.W.; CONNOR-WARD, D.V.; NEWELL, C.A.; MCDONELL, R.E.; SATO, S.J.; GASSER, C.S.; FISHHOFF, D.A.; RE, D.B.; FRALEY, R.T.; HORSCH, R.B. Production of transgenic soybean plants using Agrobacterium-mediated DNA transfer. Nature Biotechnology, v.6, p.915-922, 1988.

HOMRICH, M.S.; PASSAGLIA, L.M.P.; PEREIRA, J.F.; BERTAGNOLLI, P.F.; PASQUALI, G.; ZAIDI, M.A.; ALTOSAAR, I.; BODANESE-ZANETTINI, M.H. Resistance to Anticarsia gemmatalis Hübner (Lepidoptera, Noctuidae) in transgenic soybean (Glycine $\max (\mathrm{L}$.) Merrill, Fabales, Fabaceae) cultivar IAS5 expressing a modified Cry1 Ac endotoxin. Genetics and Molecular Biology, v.31, p.522-531, 2008.

JEFFERSON, R.A. Assaying chimeric genes in plants: the GUS gene fusion system. Plant Molecular Biology Reports, v.5, p.387-405, 1987.

KERESZT, A.; LI, D.; INDRASUMUNAR, A.; NGUYEN, C.D.; NONTACHAIYAPOOM, S.; KINKEMA, M.; GRESSHOFF, P.M. Agrobacterium rhizogenes-mediated transformation of soybean to study root biology. Nature Protocols, v.2, p.948-952, 2007.

LI, J.; TODD, T.C.; TRICK, H.N. Rapid in planta evaluation of root expressed transgenes in chimeric soybean plants. Plant Cell Reports, v.29, p.113-123, 2010.
MANGEON, A.; MAGIOLI, C.; MENEZES-SALGUEIRO, A.D.; CARDEAL, V.; OLIVEIRA, C. de; GALVÃO, V.C.; MARGIS, R.; ENGLER, G.; SACHETTO-MARTINS, G. AtGRP5, a vacuole-located glycine-rich protein involved in cell elongation. Planta, v.230, p.253-265, 2009.

MAZAREI, M.; YING, Z.; HOUTZ, R.L. Functional analysis of the Rubisco large subunit ÂN-methyltransferase promoter from tobacco and its regulation by light in soybean hairy roots. Plant Cell Reports, v.17, p.907-912, 1998.

MURASHIGE, T.; SKOOG, F. A revised medium for rapid growth and bioassays with tobacco tissue cultures. Physiologia Plantarum, v.15, p.473-497, 1962.

PREISZNER, J.; VAN TOAI, T.T.; HUYNH, L.; BOLLA, R.I.; YEN, H.H. Structure and activity of a soybean $A d h$ promoter in transgenic hairy roots. Plant Cell Reports, v.20, p.763-769, 2001.

SAVKA, M.A.; RAVILLION, B.; NOEL, G.R.; FARRAND, S. Induction of hairy roots on cultivated soybean genotypes and their use to propagate the soybean cyst nematode. Phytopathology, v.80, p.503-508, 1990.

SCHMIDT, M.A.; LaFAYETTE, P.R.; ARTELT, B.A.; PARROTT, W.A. A comparison of strategies for transformation with multiple genes via microprojectile-mediated bombardment. In Vitro Cellular and Developmental Biology - Plant, v.44, p.162-168, 2008.

SUBRAMANIAN, S.; GRAHAM, M.Y.; YU, O.; GRAHAM, T.L. RNA interference of soybean isoflavone synthase genes leads to silencing in tissues distal to the transformation site and to enhanced susceptibility to Phytophthora sojae. Plant Physiology, v.137, p.1345-1353, 2005.

WIEBKE-STROHM, B.; DROSTE, A.; PASQUALI, G.; OSORIO, M.B.; BÜCKER-NETO, L.; PASSAGLIA, L.M.P.; BENCKE, M.; HOMRICH, M.S.; MARGIS-PINHEIRO, M.; BODANESE-ZANETTINI, M.H. Transgenic fertile soybean plants derived from somatic embryos transformed via the combined DNA-free particle bombardment and Agrobacterium system. Euphytica, v.177, p.343-354, 2011.

Received on May 11, 2011 and accepted on September 5, 2011 